\title{
Management of Construction Waste in Nuclear and Thermal Power Plant Projects in India
}

\author{
*Sathiyamurthy Seethapathy' and Jane Helena Henderson²
}

\begin{abstract}
Published online: 24 November 2017
To cite this article: Sathiyamurthy Seethapathy and Jane Helena Henderson. (2017). Management of construction waste in nuclear and thermal power plant projects in India. Journal of Construction in Developing Countries, 22(Supp. 1): 19-46. https://doi.org/10.21315/jcdc2017.22.suppl.2
\end{abstract}

To link to this article: https://doi.org/10.21315/jcdc2017.22.supp1.2

\begin{abstract}
Waste in construction is important both from the perspective of productivity and from environmental considerations. Mostly actual quantum of waste generation exceeds the percentage envisaged initially, causing needless utilization of both natural and human resources. It is understood from project and construction managers during site survey that there is plenty of scope for enhancing project productivity simply by minimizing waste out of construction and also saving the cost as well as extraction of natural resources. This paper attempts to identify the causes towards generation of waste of different types of building materials during various stages of construction in different power plant projects in India. Subsequent to identification, methods are proposed to mitigate the generation of construction wastes by adopting appropriate construction and management checks and methods, which allow waste reduction. The use of various building materials in different types of projects has different impact on the amount of waste generation, environment, and cost. Research data were gathered from the analysis of five power plant projects under construction or already completed in different states in India. The causes of such occurrences of each item and details have been analysed from the questionnaire survey and the same was processed for normalizing, data cleaning, and reliability analysis done through SPSS. The result of the first questionnaire was used along with site inputs/factual data to project the tabulation of perception versus reality. Furthermore, a second questionnaire was initiated for the validation of the above using non parametric statistic test and suitable recommendations were given to reduce wastage. The research paper reveals the major root causes for material wastage in construction of power plant projects and proper awareness to be created to the relevant project team by training. The findings of this paper would help in enhancing project productivity during construction, cost savings to the extent of $1.667 \%$ to $1.941 \%$ of total project cost and minimizing the extraction of natural resources.
\end{abstract}

Keywords: Concrete structures, Infrastructure planning, Waste management, Power plant, Construction materials

\section{INTRODUCTION}

Wastes are defined as unwanted or discard material (Ferguson et al., 1995; Winkler, 2010). Wastes continually cause environmental troubles and global warming problems to the world (Desa, Kadir and Yusooff, 2011; Sakai et al., 2011). Waste management for construction activities has been promoted with the aim of protecting the environment and the recognition that wastes from construction and demolition works contribute significantly to the polluted environment (Shen and

\footnotetext{
'Larsen and Toubro Limited, 979, Manapakkam, Chennai, Tamilnadu, INDIA ${ }^{2}$ College of Engineering, Guindy, Anna University, Chennai, Tamilnadu, INDIA

"Corresponding author: sathyaa@Lntecc.com
} 
Tam, 2002). However, it is specified in Environment Protection Department (EPD, 2002) that the responsibility for ensuring the construction activities and products consistent with environmental policies needs to be defined and good environmental practices through reduction of wastes needs to be improved.

It is quite evident from the above that construction waste minimization and its management has become a serious and challenging environmental issue in developing cities all over the world today. It is very difficult to recycle and reuse construction waste due to high level of contamination and heterogeneity. Hence, its prevention and minimization plays a vital role in project management. Depleting natural resources, increasing pollution, scarcity of dumping yards, destruction to the natural environment and habitat leading to ecological imbalance etc. are some of the negative impacts of construction and demolition (C\&D) waste. Failing to take immediate action in its reduction and management will lead to depletion of the natural resources and land fill spaces. Though some amount of construction waste cannot be avoided, the potential cost reduction by preventing generation of construction waste on site is substantial. Minimization of construction waste is important not only from the perspective of enhancing the project productivity but also from environmental considerations.

Environmental protection is an important issue throughout the world (Tse, 2001). Compared with other industries, construction is a main source of environmental pollution (Shen et al., 2005). Building construction and operations have a massive direct and indirect effect on the environment (Levin, 1997). Pollution sources from the construction process include harmful gases, noise, dust, and solid and liquid wastes (Chen, Li and Wong, 2000). This issue has prompted many construction participants to attempt to control the impacts of their activities by adopting environmental management systems (Lam et al., 2011). Awareness and knowledge are the main factors to intensify the sustainability movement (Zainul Abidin, 2010). The Malaysian government, professional bodies, and private organizations have started several programmes to enhance the awareness and knowledge of construction practitioners, and to promote the application of sustainable principles within construction projects (Zainul Abidin, 2010). It is understood from the site factual records that many times actual percentages of waste generation are much higher than those considered at initial project stage.

The requirement of electricity in India is continually increasing and establishment of power plants are happening to meet out the total demand (McKinsey \& Company, 2008). The power generation can be made through thermal, nuclear, solar, wind, and hydel energies. The higher capacity of power generation is being pre-dominantly made through nuclear and thermal plants. Both nuclear and thermal power plant structures are more complex in nature since it consists of reactor building, turbine building, natural and induced draft cooling towers, cooling water pump house, boiler building, chimneys, stacker reclaimer building, electro static precipitator building, switch yard, fuel storage facilities, and other related structures that require expertise in construction. It is also understood from the project and construction managers during the site survey that the thermal and nuclear power plant projects have more issues in different stages like planning and execution and have larger avenue for focusing and controlling the construction waste.

This paper focuses on source identification of construction waste and approaches of managing it in power plant projects in India. A waste management plan is designed and illustrated that will guide to effectively use these approaches. The paper also comprises key issues in implementation of waste management 
strategy in various phases of nuclear and thermal power plant projects in India. Observations and conclusions are based on the material waste study carried out on five different power plant projects in India.

\section{PREVIOUS STUDY ON WASTAGE IN CONSTRUCTION}

The causes for the construction waste in Indonesia are design changes, lack of trade skill, slow in making decisions, poor co-ordination among project participants, poor planning and scheduling, delay of material delivery to site, and inappropriate construction methods. Similarly, in Australia the causes are design changes, poor design, poor quality site documentation, slow drawing revision and distribution, unclear site drawings supplied, unclear specifications, and weather (Alwi, Hampson and Mohamed, 2002).

Recent literature studies have defined waste as losses that are produced by activities, which result in direct or indirect costs but do not add any value to the product from the point of view of the client (Koshy and Apte, 2012).

A study was conducted on implementation of waste management and minimization in the Malaysian construction industry and categorized waste minimization into source reduction and recycling. Source reduction is defined as any activity that reduces or eliminates the generation of waste at source, usually within a process, and recycling as the recovery and/or re-use of what would otherwise be a waste material. The most important sources of waste in construction and possible measures for minimization of waste in Singapore was studied, and the need to avoid design changes during construction was emphasized (Ekanayake and Ofori, 2000).

The waste identification and assessment in power plant projects had been approached by lean management. It was separated into seven groups i.e. overproduction, defect (correction and rework), inventory, transportation, waiting, motion, and over processing. The causes had been analysed based on the groups in power plant projects in Tehran (Rashid and Heravi, 2012).

In Ghana, the consultants perceive that purchasing raw materials that are just sufficient, using materials before expiry dates, use of more efficient construction equipment and good coordination between store and construction personnel to avoid over-ordering as the measures that highly contribute to waste minimization and those that are highly practiced (Agyekum, Ayarkwa and Adinyira, 2012). Encouraging re-use of waste materials in projects, using low waste technology and recycling of some waste materials on sites are perceived as measures with low contribution to waste reduction and those that are least practiced.

Waste management in construction activities was initiated with a target of protecting the environment by reducing the exploration of the natural resources and the recognition that wastes from construction and demolition works contribute significantly to the polluted environment (Shen and Tam, 2002). As specified by Shen et al. (2002) and Tse (2001), the construction industry plays a vital role in meeting the needs of society and enhancing the quality of life. However, the responsibility for ensuring that construction activities and products are consistent with environmental policies needs to be defined through good environmental practices as per EPD (2002). Normally, the best way to deal with material waste is not to create it in the first place (Gavilan and Bernold, 1994; EPD, 2002). 
Waste leads to inefficiency that results in the excess use of many key construction resources such as men, material, machinery, money or any other key resource, which are tangible than those estimated as necessary in the production of an item. Construction waste becomes a non-value adding activity that always affects project performance in the form of cost overruns and/or delays. Globally, building waste production of 2 to 3 billion ton per year is estimated (Shrivastava and Chini, 2012). According to statistical data, C\&D debris frequently makes up $10 \%$ to $30 \%$ of the waste received at many landfill sites around the world (Begum et al., 2007). The quantum of solid waste generation in India is to the tune of 48 million ton per annum of which waste from construction industry accounts for $25 \%$ i.e. around 12 million ton per year, according to Technology Information Forecasting and Assessment Council (TIFAC, 2000). It is found that up to $30 \%$ of construction is rework, labour is used at only $40 \%$ to $60 \%$ of potential efficiency, accidents accounts for $3 \%$ to $6 \%$ of total project cost, and at least $10 \%$ of materials are wasted (Richardson, 2013). This indicates a huge scope to achieve higher productivity, just by removing waste out of construction, leading to sustainable construction. It is found that $29 \%$ of the solid-wastes in the USA are construction wastes (Rogoff and Williams 1994). All these investigations demonstrate that construction business is a large contributor to waste generation and that there is significant potential for protecting the environment through minimizing construction waste efficiently.

\section{RESEARCH METHODOLOGY}

A questionnaire survey was conducted to examine the effectiveness of existing requirements in implementing the waste management method for construction of power plant projects. A preliminary quantitative study was carried out to investigate the perception of contractor's representatives consisting of project managers, construction managers, planning managers, planning engineers, site in-charges, field engineering personnel, site engineers, concrete co-ordinators, reinforcement co-ordinators, plant and machinery in-charge and engineers, warehouse in-charge, and supervisors at three thermal power projects (TP-1, TP-2 and TP-3) and two nuclear power project sites (NP-1 and NP-2) regarding construction waste causes, as shown Table 1. Convenience sampling was used in this research as we had a diverse set of experienced engineers working in projects, which formed the part of analysis. We had achieved a $100 \%$ response rate as it was our own company project.

Table 1. Details of The Power Plant Projects

\begin{tabular}{cccccc}
\hline Sl. No. & Description of the Project & Capacity & Type & Status & Id \\
\hline 1 & Nuclear Power Plant Project & $2 \times 700 \mathrm{MWe}$ & Nuclear & Ongoing & NP-1 \\
2 & Nuclear Power Plant Project & $2 \times 700 \mathrm{MWe}$ & Nuclear & Ongoing & NP-2 \\
3 & Thermal Power Plant Project & $1 \times 500 \mathrm{MW}$ & Thermal & Completed & TP-1 \\
4 & Thermal Power Plant Project & $1 \times 600 \mathrm{MW}$ & Thermal & Completed & TP-2 \\
5 & Thermal Power Plant Project & $2 \times 600 \mathrm{MW}$ & Thermal & Completed & TP-3 \\
\hline
\end{tabular}


The identification of the waste caused by the material is significant as waste source detection (Hassan et al., 2015). The methodology used in this study is site observations and interviews with site personnel. The study found the similarity in terms of the two major contributors; the management and the workers. From the study, the factors that cause waste to be generated are highlighted and the waste site checklist according to the material can be developed as a guideline for the site personnel and site management.

Ninety-four causes had been reached from initial interaction and the same is further pruned down to 58 causes as shown in Tables 2 and 3, which are contributing major impact.

Table 2. Issues Related to Planning and Execution

\begin{tabular}{|c|c|c|}
\hline SI. No. & Description & Causes \\
\hline 1 & Engineering related & $\begin{array}{l}\text { Delay in issuance of drawings } \\
\text { Change in design } \\
\text { Change in specifications } \\
\text { Mistakes in drawings } \\
\text { Non-clarity in details }\end{array}$ \\
\hline 2 & Detailing related & $\begin{array}{l}\text { Non-usage of software for bar bending schedule } \\
\text { Ordering of specific length of reinforcement bars } \\
\text { Ordering of specific size of plates for pipe fabrication }\end{array}$ \\
\hline 3 & Material related & $\begin{array}{l}\text { Change in specification } \\
\text { Lesser shelf life } \\
\text { Poor quality } \\
\text { Excess ordering } \\
\text { Change of source of basic materials }\end{array}$ \\
\hline 4 & $\begin{array}{l}\text { Storage and handling } \\
\text { related }\end{array}$ & $\begin{array}{l}\text { Improper storage } \\
\text { Improper accounting } \\
\text { Multiple handling } \\
\text { Deficiency in quantity received }\end{array}$ \\
\hline 5 & $\begin{array}{l}\text { Plant and machinery } \\
\text { related }\end{array}$ & $\begin{array}{l}\text { Non-calibration of equipment } \\
\text { Non-maintenance of equipment } \\
\text { Non-cleaning of equipment }\end{array}$ \\
\hline 6 & Production related & $\begin{array}{l}\text { Measurement of materials for concrete } \\
\text { Rolling margin of reinforcement bars } \\
\text { Re-use of scraps }\end{array}$ \\
\hline 7 & Execution related & $\begin{array}{l}\text { Non-involvement of skilled workmen } \\
\text { Bad workmanship } \\
\text { Improper supervision of works } \\
\text { Incorrectness in ordering of concrete quantity } \\
\text { Fabrication of major pipes and embedded parts at site } \\
\text { Idling of equipment }\end{array}$ \\
\hline 8 & Management related & $\begin{array}{l}\text { Non-accountable of materials } \\
\text { Non-training of personnel } \\
\text { Lack of awareness - encouragement through incentives }\end{array}$ \\
\hline
\end{tabular}


Table 3. Issues Related to Procurement, Storage and Usage

\begin{tabular}{|c|c|c|}
\hline SI. No & Description & Causes \\
\hline 1 & Concrete & $\begin{array}{l}\text { Improper planning } \\
\text { Excess quantity ordering } \\
\text { Improper maintenance of plant and machinery }\end{array}$ \\
\hline 2 & Reinforcement steel & $\begin{array}{l}\text { Improper storage } \\
\text { Improper cutting plan } \\
\text { Deficiency in the quantity received } \\
\text { Pilferage of the material } \\
\text { Non-accountable due to rolling margin }\end{array}$ \\
\hline 3 & Formwork & $\begin{array}{l}\text { Improper storage } \\
\text { Non-availability of drawings } \\
\text { Lack of reusability }\end{array}$ \\
\hline 4 & Blocks & $\begin{array}{l}\text { Improper storage } \\
\text { Multiple handling } \\
\text { Deficiency in quantity received }\end{array}$ \\
\hline 5 & Cement & $\begin{array}{l}\text { Improper storage } \\
\text { Multiple handling } \\
\text { Deficiency in quantity received } \\
\text { Variance while batching due to improper calibration }\end{array}$ \\
\hline 6 & Coarse aggregate & $\begin{array}{l}\text { Improper storage } \\
\text { Multiple handling } \\
\text { Deficiency in quantity received } \\
\text { Variance while batching due to improper calibration }\end{array}$ \\
\hline 7 & Fine aggregate & $\begin{array}{l}\text { Improper storage } \\
\text { Multiple handling } \\
\text { Deficiency in quantity received } \\
\text { Variance while batching due to improper calibration }\end{array}$ \\
\hline
\end{tabular}

From the identified causes, a structured questionnaire is designed into 2 stages consisting of 15 categories and all the categories are grouped by 58 causes as indicated in Figure 1. The range of occurrences is scaled with nine scales similar to Likert's method.

The first questionnaire was analysed in stages. Demographic descriptive study was done for raw data obtained from the first survey. The demographic study included classifications based on department, experience (overall and relevant), project group, and type. This was undertaken to study the broad outlook of the selected population sample and extended to a comparison of perception based on survey with reality inferred from site inputs and factual data.

The t-test and ANOVA techniques were used to test few hypotheses. A hypothesis test is a statistical test that is used to determine whether there is enough evidence in a sample data collected to infer that a certain condition is true for the entire population. It examines two opposing hypotheses; the null hypothesis and the alternative hypothesis. 


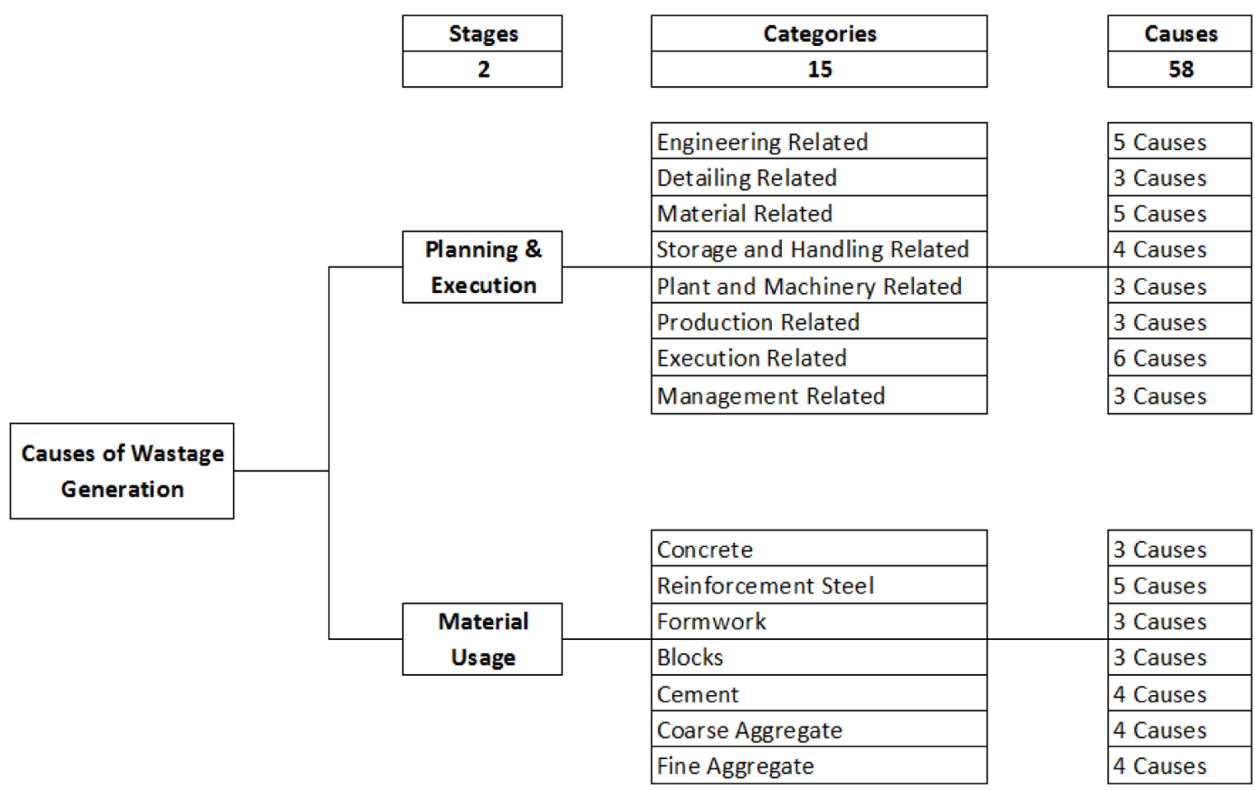

Figure 1. Causes of Wastage Generation

Independent sample t-test compares the means of two groups of cases while an ANOVA technique is used when there are more than two groups. In this paper, the test variables were those that had been calculated based on the responses in the sample to various questions asked in the questionnaire administered and the grouping variables were the demographic details of the respondents.

Variables like Engineering Related, Detailing Related, Materials Related, etc. were test variables calculated by the researcher based on the responses. The means of these variables were calculated and tested for statistically significant differences between groups based on type of project, designation, experience, etc.

T-test was used for grouping variables like Project Type (thermal and nuclear), relevant experience (up to 3 years and $>3$ years); Designation (site engineers and others), and Departments (execution and others), since there were only two groups in these variables.

For grouping variable (a) five different types of projects in the study and (b) three different groups based on total experience, ANOVA Technique was used since there were more than two groups in these variables.

Based on the above major causes of wastage contributing more than $90 \%$ of the overall cost of wastage of project are tabulated. Besides, the aim of this paper is to provide appropriate wastage control measures to mitigate the above arrived causes.

To validate the results from the above process, an exclusive second questionnaire was developed and the same was given to the two recently completed projects. Second questionnaire survey results were tested for concordance between projects. The test is used to assess any similarity of opinion between groups on the issues of waste generation. Data collected from both questionnaires were chosen to analyse using SPSS and Microsoft Excel. 


\section{DATA COLLECTION IN THERMAL AND NUCLEAR POWER PLANTS IN INDIA}

A survey was conducted for a period of 30 months in 5 different power plant projects during 2013 to 2015 (TP1 - August 2013 to October 2013, TP2 - November 2013 to January 2014, TP3 - February 2014 to April 2014, NP1 - October 2014 to December 2014, and NP2 - January 2015 to March 2015) to expound the reasons due to which wastage is generated during major infrastructure projects. This research was effectuated to unravel the root cause illustrating why wastages occur during construction. Material wastage is emblematized as the difference between the value of materials delivered and accepted on site and those properly used as specified and accurately measured in the work after deducting the cost saving of substituted materials transferred elsewhere in which unnecessary cost and time may be increased (Shen and Tam, 2002). Wastage can be assayed as any inefficiency that results in the use of equipment, materials labour, or capital in larger quantities than those considered as necessary in the production of a building (Koskela, 1992). Recent literature studies have defined waste as losses that are produced by activities that result in direct or indirect costs but do not add any value to the product from the point of view of the client (Koshy and Apte, 2012). Two dominant stages were identified in earlier research works, which could be controlled to reduce material wastages. They were - the design stage and the management stage (Chandler, 1978). This can be related to stages where the design phase can be inferred to procurement, materials storage, material usage etc., and management phase can be deciphered as the planning and executing the scheduled activities regarding construction. Hence, the survey questionnaire was also architected based on two facets namely the planning and execution phase and the procurement and storage phase. As this was also evidenced by sovereign elements in the literature studies, 58 elements encrypting the causes for material wastage were drafted as a survey questionnaire and data was collected from 500 respondents in various projects from India to quantify the occurrences where wastage was generated in different projects as indicated in Figure 2.

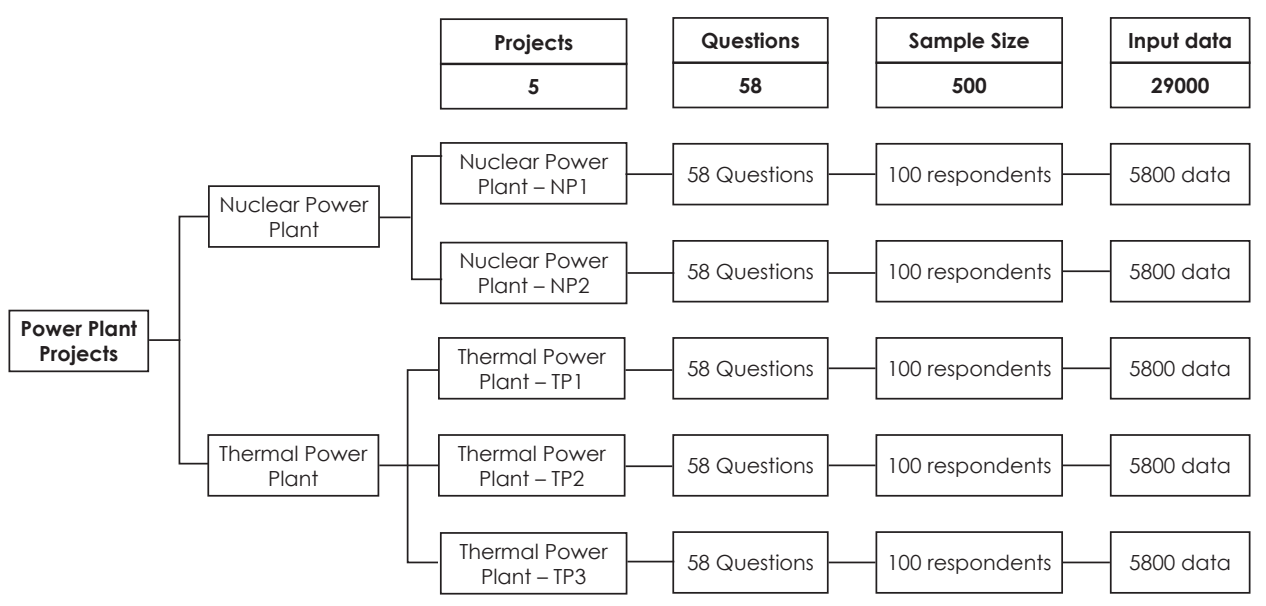

Figure 2. Process of Data Collection 
The following factual data are collected from all the five project sites to arrive the cost component:

1. Total project cost for civil works.

2. Quantities of various grades of concrete, reinforcement steel, form work, block work etc.

3. Design mix for concrete.

4. Cost of individual materials like cement, fine aggregate, coarse aggregate, reinforcement steel, form work, plywood, timber, etc.

5. Percentage of individual material wastage component prevailing at site.

\section{Issues at Planning and Execution Stages}

The following were the findings from the data collected through questionnaire.

\section{Engineering Related issues}

It is understood from the site survey that both thermal and nuclear power plants are executed on design and construction basis except main plant structures of nuclear power plants. It is understood from the planning managers during the site survey that the procurement strategy towards ordering of various construction materials are dependent on the completion of engineering and detailed design. It is understood from the site survey that different materials have different lead times and keeping the stock in the warehouse is subject to availability of drawings. The material wastage pertains to the various engineering related issues:

1. Delay in issuance of drawings;

2. Changes in design during construction;

3. Change in specification during construction;

4. Mistakes in drawings; and

5. Non-clarity of the drawings.

\section{Detailing Related issues}

The detailing of work pertains to various cutting plan, preparation of shop drawings and related schedules, are playing important role in generating material wastage. Detailed cutting plans are required for reinforcement steel and structural steel to have an efficient utilization of available material and minimizing the wastages. Timely preparation and delivery of proper shop drawings result in efficient method of construction and minimize the duplication of the works. From the data collected, it is understood that the projects faced issues like:

1. Improper cutting plan;

2. Improper bar bending schedule; and

3. Improper planning of material usage. 


\section{Material Related issues}

Supply chain management plays a vital role in proper management of construction materials. All construction materials are received and safely stored in the warehouse. The various construction materials required at different stages are planned and procured well in advance as every material has different lead times. It is understood that many times improper procedure or method is adopted while receiving the materials by either weighing or measuring. This results in improper accounting in receipt of materials. It is understood from the data that the wastages are generated primarily due to:

1. Material having lesser shelf life;

2. Ordering poor quality material;

3. Change in specification during the project execution;

4. Excess quantity order; and

5. Change in source for the bulk materials.

It is also noted that the volume of reinforcement steel is not reduced while placing the order for supply of concrete. The lesser shelf life of materials contributes in generation of wastage.

\section{Storage and Handling Related issues}

The space required for the storage of materials depends on the duration of the project. It is understood from the data that every project site has restriction in land area availability as these projects are augmentation of the existing power plants. The limited storage space leads to temporary storing of materials at one place initially and subsequent to shifting to the required place. It is evident that project requires more stock towards coarse and fine aggregates and area of batching plant is restricted to have limited storage. Materials such as fine aggregate, bricks, and blocks always tend to get lost and broken due to multiple handling. From the data analysis, it is found that the reasons are:

1. Improper storage of materials;

2. Improper accounting;

3. Multiple handling of the materials; and

4. Deficiency in quantity receipt.

All the prime factors leading to wastage towards improper storage of materials contributes to generation of wastage of materials.

\section{Plant and Machinery Related issues}

Plant and machinery such as batching plant, transit mixers, mortar mixers, and concrete pumps are used in construction sites. These are considered to be one of the key resources. It is recommended by the manufacturer to have periodic maintenance to achieve desired results. It is evident that the project site has continuous concreting activities and the required maintenance activities have not taken place for major equipment such as batching plants, transit mixer, concrete pumps, etc. The major reasons for generating material wastages are: 
1. Improper periodic maintenance;

2. Improper calibration of equipment; and

3. Improper cleaning of equipment.

It is understood from the plant and machinery in-charge that all the above reasons lead to concrete quality issues and subjected to rejection for not achieving the desired strength of concrete.

\section{Production Related issues}

Construction site produces concrete either by captive batching plant or ready mix concrete plant. Improper calibration and improper maintenance of such batching plant result in improper measurement of basic materials. Trained personnel are required to maintain and operate the batching plant more efficiently. Similarly, the reinforcements are cut and bent at site. It is understood that non-accounting of rolling margin is one of the key reasons of using excess reinforcement steel in the project sites. The other reason is not having a co-ordinated procedure to have a centralized steel yard to ensure the effective utilization of scrap steel in another suitable location. The measurement of materials while batching for concrete production also contributes to generation of wastage of materials.

\section{Execution Related issues}

Apart from the key resource of material and machinery, the construction work requires human resource to have an effective and successful completion of the project. It is understood that non-deployment of proper skilled workmen results in bad workmanship and rework of the same. Non-deployment of proper supervisors leads to incorrect ordering of concrete quantity and idling of equipment. The incorrectness in ordering of concrete quantity contributes to generation of material wastage.

\section{Management Related issues}

The top management of the organization needs to give necessary training for personnel towards controlling material wastage and proper accounting of materials between receipt and actual consumption. In-house training or external training is not properly provided to the staff members. Incentives for enabling the wastage control process have not been implemented across the staff members by the management. Many organizations had not implemented such schemes and these results in wastage of the materials.

\section{Issues at Material Procurement, Storage and Usage Stages}

Power plant project construction requires various basic materials i.e. cement, fine aggregate, coarse aggregate, bricks, concrete blocks, reinforcement steel, structural steel, and concrete. It is understood from the site survey during factual data collection that basic materials are contributing major cost and conscious focus to be made towards controlling the basic material wastages. 


\section{Concrete}

Concrete is the prime material for construction and being used for both substructure and super structure of power plant structures. The production of concrete is normally done by batching plant at site itself. In case of restriction in space and environmental issues at project site, the concrete is produced and supplied from ready mix plant. It is understood from planning managers during site survey that the major quantity of wastage is between ordered quantity based on theoretical measurements and actual requirement poured at site. The exact quantity is not known due to improper planning and non-deduction of cut outs and reduction for reinforcement volume. This excess ordering of concrete results in wastage. Improper planning in making the site fronts and improper pour plans lead to delay in pouring concrete. This generates wastage as the concrete crosses the initial setting time and not used for the specific pour. Improper maintenance of plant and machinery generates wastage as the equipment is repaired during the production or pouring of concrete. The improper planning and excess quantity ordering of concrete contribute to generation of wastage of materials.

\section{Reinforcement}

The main cause of wastage of reinforcement steel is due to improper cutting and bending and making improper cutting plans. The non-deployment of skilled workmen leads to improper cutting and bending of reinforcement steel. Nonusage of automated equipment and software for cutting plans are also leading to generation of material wastage. It is evident from the site survey that ordering of project specific length of reinforcement steel is not implemented. It is also found that the damages occurred towards improper storage leading to rusting, forms one of the major part of wastage. Pilferage of reinforcement steel occurred due to shortage of storage space leading to stacking the steel in different locations. The reinforcement steel is bought during different periods of time and the allowance of the rolling margin is not taken into consideration. This non-accountable rolling margin results in consumption of more quantity of reinforcement steel than actual requirement.

\section{Formwork}

The type of form used is either of steel or timber board with plywood back-up. Majority of the form work are made using timber board. The prime reasons of wastage are the natural deterioration during usage and cutting while making the formwork to the required shape and size. These two occurrences are to be avoided to the extent possible. Improper planning and delay in construction activities leads to minimum number of usability of form work than originally planned. It is understood from the survey that the delay in construction happened due to non-availability of the detailed drawings. The lack of reusability of formwork contributes to generation of wastage of materials. 


\section{Block}

Concrete blocks are the most common filling and walling material used for making solid walls as well as partitions. The reason for wastage is due to cutting of the edges to match the required shape. Improper storage and multiple handling also contribute to wastage. It is understood that proper bedding was not made to store the bricks/concrete blocks. The survey also revealed that majority of the wastage is due to multiple handling and improper method of transporting and lifting the materials to respective project locations. The improper storage of brick and block also contributes to generation of wastage of materials.

\section{Cement, Fine Aggregate and Coarse Aggregate}

Ready mix concrete is used in all projects and the major reasons for wastage of cement, fine aggregate, and coarse aggregate are due to improper storage, multiple handling, deficiency in quantity received and variance while batching due to improper calibration.

\section{DATA ANALYSIS AND RESULT VALIDATION}

Demographic study was performed to analyse the trend of the survey data. Hypothesis testing (refer Tables 4 and 5) was also undertaken under the following criteria:

1. Demographics Study of Raw Data-Departments, Overall Experience, Relevant Experience, Group and Type (refer Figures 3-7).

2. Custom Tabulation: Planning \& Execution - Engineering related, Detailing related, Material related, Storage and Handling related, Plant and Machinery related, Production related, Execution related, and Management related causes.

3. Custom Tabulation: Procurement and Storage, Concrete, Reinforcement Steel, Formwork, Bricks and Blocks, Cement, Coarse and Fine Aggregates.

4. T-Test - Macro Causes for Wastages and Material Wastages: Relevant Experience, Designation, Departments, Project Type.

5. ANOVA - Macro Causes for Wastages and Material Wastages: Group Test, Total Experience.

6. Pattern Matrix - Macro Causes of Construction Wastage and Material Wastage Determinants (refer Tables 6-8).

7. Perception versus Reality-Macro Causes of Construction Wastage and Material Wastage Determinants (refer Tables 9 and 10).

8. Exploratory Factor Analysis - Macro Causes of Construction Wastage and Material Wastage Determinants.

Considering all the five type of projects together, this study progresses further to explore whether there is a significant difference between the real life construction wastages and the amount of wastage that is perceived by the sample population. This formulation (refer Tables 9 and 10) becomes the backbone of the research and is the ultimate terminal of findings. 
Table 4. Hypotheses Testing - Macro Causes of Wastage

\begin{tabular}{|c|c|c|c|c|}
\hline $\begin{array}{c}\text { Case } \\
\text { No }\end{array}$ & Category & $\begin{array}{c}\text { Test/ } \\
\text { Condition }\end{array}$ & Hypotheses Result & Inference \\
\hline $\begin{array}{l}\mathrm{HlO} \\
\mathrm{Hla}\end{array}$ & $\begin{array}{l}\text { Relevant } \\
\text { experience }\end{array}$ & \multirow{4}{*}{ T-Test } & $\begin{array}{l}\text { Null hypotheses } \\
\text { rejected }\end{array}$ & $\begin{array}{l}\text { Reinforcement steel and cement } \\
\text { were one of the prominent causes } \\
\text { of macro wastage. }\end{array}$ \\
\hline $\begin{array}{l}\mathrm{H} 3 \mathrm{O} \\
\mathrm{H} 3 \mathrm{a}\end{array}$ & Designation & & $\begin{array}{l}\text { Null hypotheses } \\
\text { rejected }\end{array}$ & $\begin{array}{l}\text { Detailing issues, an important } \\
\text { determinant in planning and } \\
\text { execution and reinforcement } \\
\text { steel, a primal role in procurement } \\
\text { and storage of macro wastage. }\end{array}$ \\
\hline $\begin{array}{l}\mathrm{H} 50 \\
\mathrm{H} 5 \mathrm{a}\end{array}$ & Department & & $\begin{array}{l}\text { Null hypotheses } \\
\text { rejected }\end{array}$ & $\begin{array}{l}\text { Detailing issues, an important } \\
\text { determinant in planning and } \\
\text { execution and reinforcement } \\
\text { steel, a primal role in procurement } \\
\text { and storage of macro wastage. }\end{array}$ \\
\hline $\begin{array}{l}\mathrm{H} 7 \mathrm{O} \\
\mathrm{H} 7 \mathrm{a}\end{array}$ & \multirow{2}{*}{ Project type } & & $\begin{array}{l}\text { Null hypotheses } \\
\text { rejected }\end{array}$ & $\begin{array}{l}\text { Execution related variables play a } \\
\text { preponderant role in reducing the } \\
\text { amount of macro wastage. }\end{array}$ \\
\hline $\begin{array}{l}\mathrm{H} 9 \mathrm{O} \\
\mathrm{H} 9 \mathrm{a}\end{array}$ & & \multirow{2}{*}{ ANOVA } & $\begin{array}{l}\text { Null hypotheses } \\
\text { rejected }\end{array}$ & $\begin{array}{l}\text { Execution related variables play a } \\
\text { preponderant role in reducing the } \\
\text { amount of macro wastage. }\end{array}$ \\
\hline $\begin{array}{l}\mathrm{H} 110 \\
\mathrm{H} 11 \mathrm{a}\end{array}$ & Project group & & $\begin{array}{l}\text { Null hypotheses } \\
\text { rejected }\end{array}$ & $\begin{array}{l}\text { Detailing related issues and } \\
\text { cement related issues are prime } \\
\text { sources of generating wastage. }\end{array}$ \\
\hline $\mathrm{H} 13 \mathrm{a}$ & $\begin{array}{l}\text { Overall } \\
\text { variables }\end{array}$ & $\begin{array}{l}\text { Pattern } \\
\text { matrix }\end{array}$ & $\begin{array}{l}\text { Null hypotheses } \\
\text { rejected }\end{array}$ & $\begin{array}{l}\text { There is a significant impact of } \\
\text { predictors on criterion variables like } \\
\text { experience (overall and relevant), } \\
\text { groups, projects, designation, and } \\
\text { departments. }\end{array}$ \\
\hline $\mathrm{H} 150$ & Project type & $\begin{array}{l}\text { Perception } \\
\text { vs reality }\end{array}$ & $\begin{array}{l}\text { Null hypotheses } \\
\text { rejected }\end{array}$ & $\begin{array}{l}\text { There is a significant difference } \\
\text { between the real and the } \\
\text { perceived level of macro causes } \\
\text { of wastage, based on types of } \\
\text { projects. }\end{array}$ \\
\hline
\end{tabular}

There is a quest to unravel a concept of reality based on the ranks given by the engineers on their cognition of wastage and the actual level of wastage that take place in construction. This is facilitated based on the research hypotheses.

Ho: There is no significant difference between the real and the perceived level of macro causes of wastage, based on five different types of projects i.e. two nuclear and three thermal projects in construction.

Ha: There is a significant difference between the real and the perceived level of macro causes of wastage, based on five different types of projects i.e. two nuclear and three thermal projects in construction. 
Table 5. Hypotheses Testing - Material Wastage

\begin{tabular}{|c|c|c|c|c|}
\hline $\begin{array}{c}\text { Case } \\
\text { No }\end{array}$ & Category & Test / Condition & Hypothesis Result & Inference \\
\hline $\begin{array}{l}\mathrm{H} 2 \mathrm{O} \\
\mathrm{H} 2 \mathrm{a}\end{array}$ & $\begin{array}{l}\text { Relevant } \\
\text { experience }\end{array}$ & & $\begin{array}{l}\text { Null hypotheses } \\
\text { rejected }\end{array}$ & $\begin{array}{l}\text { Reinforcement steel was } \\
\text { the prime cause for material } \\
\text { wastage, followed by } \\
\text { formworks and blocks. }\end{array}$ \\
\hline $\begin{array}{l}\mathrm{H} 4 \mathrm{O} \\
\mathrm{H} 4 \mathrm{a}\end{array}$ & Designation & & $\begin{array}{l}\text { Null hypotheses } \\
\text { rejected }\end{array}$ & $\begin{array}{l}\text { Reinforcement steel was one } \\
\text { of the major causes of material } \\
\text { wastages while constructing } \\
\text { several projects. }\end{array}$ \\
\hline $\begin{array}{l}\mathrm{H} 6 \mathrm{O} \\
\mathrm{H} 6 \mathrm{a}\end{array}$ & Department & & $\begin{array}{l}\text { Null hypotheses } \\
\text { rejected }\end{array}$ & $\begin{array}{l}\text { Reinforcement steel was one } \\
\text { of the major causes of material } \\
\text { wastages while constructing } \\
\text { several projects. }\end{array}$ \\
\hline $\begin{array}{l}\mathrm{H} 8 \mathrm{O} \\
\mathrm{H} 8 \mathrm{a}\end{array}$ & Project type & & $\begin{array}{l}\text { Null hypotheses } \\
\text { rejected }\end{array}$ & $\begin{array}{l}\text { Reinforcement steel was one } \\
\text { of the major causes of material } \\
\text { wastages while constructing } \\
\text { several projects. }\end{array}$ \\
\hline $\begin{array}{l}\mathrm{H} 10 \mathrm{O} \\
\mathrm{H} 10 \mathrm{a}\end{array}$ & Project type & & $\begin{array}{l}\text { Null hypotheses } \\
\text { accepted }\end{array}$ & $\begin{array}{l}\text { Concrete and reinforcement } \\
\text { steel are cognized as two } \\
\text { momentous determinants of } \\
\text { material wastage. }\end{array}$ \\
\hline $\begin{array}{l}\mathrm{H} 12 \mathrm{O} \\
\mathrm{H} 12 \mathrm{a}\end{array}$ & Project group & & $\begin{array}{l}\text { Null hypotheses } \\
\text { rejected }\end{array}$ & $\begin{array}{l}\text { Formworks as the primary } \\
\text { source, followed by blocks and } \\
\text { finally concrete as the major } \\
\text { determinants. }\end{array}$ \\
\hline $\begin{array}{l}\mathrm{H} 14 \mathrm{O} \\
\mathrm{H} 14 \mathrm{a}\end{array}$ & $\begin{array}{l}\text { Overall } \\
\text { variables }\end{array}$ & Pattern matrix & $\begin{array}{l}\text { Null hypotheses } \\
\text { rejected }\end{array}$ & $\begin{array}{l}\text { There is a significant impact of } \\
\text { predictors on criterion variables } \\
\text { like total experience, relevant } \\
\text { experience, groups, projects, } \\
\text { designation, and departments. }\end{array}$ \\
\hline $\mathrm{H} 160$ & Project type & $\begin{array}{l}\text { Perception vs } \\
\text { reality }\end{array}$ & $\begin{array}{l}\text { Null hypotheses } \\
\text { rejected }\end{array}$ & $\begin{array}{l}\text { There is a significant difference } \\
\text { between the real and } \\
\text { perceived level of macro } \\
\text { causes of wastage, based on } \\
\text { types of projects. }\end{array}$ \\
\hline
\end{tabular}

Tables 9 and 10 unravels that there are obvious differences between the actual level of wastage and the perceived level of wastage by engineers when they work in different nuclear and thermal projects.

In the first nuclear project, 33.3\% of variables pertaining to engineering related, detailing related, storage related, production related issues, and bricks and blocks were underestimated. Likewise, in addition to formworks and coarse aggregate, $26.7 \%$ of variables pertaining to execution related, management related issues were overestimated. Forty percent of variables pertaining to material related, plant and machinery related issues and concrete, reinforcement steel, cement and fine aggregate were adjudged precisely. 
Table 6. Pattern Matrix - Planning and Execution

\begin{tabular}{|c|c|c|c|c|c|c|c|}
\hline $\begin{array}{l}\text { Sl. } \\
\text { No. }\end{array}$ & Variables & $\begin{array}{c}\text { Total } \\
\text { Experience }\end{array}$ & $\begin{array}{l}\text { Relevant } \\
\text { Experience }\end{array}$ & Groups & Projects & Designation & Department \\
\hline 1) & Overall variables & $\checkmark$ & $\checkmark$ & $\checkmark$ & $\checkmark$ & & \\
\hline 2) & $\begin{array}{l}\text { Planning and } \\
\text { execution }\end{array}$ & $\checkmark$ & & $\checkmark$ & $\checkmark$ & $\checkmark$ & $\checkmark$ \\
\hline i. & Engineering related & $\checkmark$ & $\checkmark$ & & & $\checkmark$ & $\checkmark$ \\
\hline ii. & Detailing related & $\checkmark$ & $\checkmark$ & & $\checkmark$ & $\checkmark$ & $\checkmark$ \\
\hline iii. & Material related & $\checkmark$ & & & & $\checkmark$ & $\checkmark$ \\
\hline iv. & $\begin{array}{l}\text { Storage and } \\
\text { handling related }\end{array}$ & $\checkmark$ & & & $\checkmark$ & & \\
\hline v. & $\begin{array}{l}\text { Plant and } \\
\text { machinery related }\end{array}$ & $\checkmark$ & $\checkmark$ & & $\checkmark$ & $\checkmark$ & $\checkmark$ \\
\hline vi. & Production related & & & & $\checkmark$ & & \\
\hline vii. & Execution related & & & $\checkmark$ & $\checkmark$ & & \\
\hline viii. & $\begin{array}{l}\text { Management } \\
\text { related }\end{array}$ & & $\checkmark$ & & & $\checkmark$ & $\checkmark$ \\
\hline
\end{tabular}

Notes: F' values of significance at 0.005

't' test values of significance at 0.05

Table 7. Pattern Matrix - Procurement, Storage and Use

\begin{tabular}{|c|c|c|c|c|c|c|c|}
\hline $\begin{array}{l}\text { Sl. } \\
\text { No. }\end{array}$ & Variables & $\begin{array}{c}\text { Total } \\
\text { Experience }\end{array}$ & $\begin{array}{c}\text { Relevant } \\
\text { Experience }\end{array}$ & Groups & Projects & Designation & Department \\
\hline 3) & $\begin{array}{l}\text { Procurement/ } \\
\text { storage/use: }\end{array}$ & & $\checkmark$ & & & $\checkmark$ & $\checkmark$ \\
\hline i. & Concrete & & & & & $\checkmark$ & $\checkmark$ \\
\hline ii. & $\begin{array}{l}\text { Reinforcement } \\
\text { steel }\end{array}$ & & $\checkmark$ & & & $\checkmark$ & $\checkmark$ \\
\hline iii. & Formwork & $\checkmark$ & $\checkmark$ & & & $\checkmark$ & $\checkmark$ \\
\hline iv. & Bricks and blocks & $\checkmark$ & $\checkmark$ & & & $\checkmark$ & $\checkmark$ \\
\hline v. & Cement & $\checkmark$ & $\checkmark$ & $\checkmark$ & & $\checkmark$ & $\checkmark$ \\
\hline vi. & Coarse aggregates & & & & & $\checkmark$ & \\
\hline vii. & Fine aggregates & & & & & $\checkmark$ & $\checkmark$ \\
\hline
\end{tabular}

Notes: F' values of significance at 0.005

't' test values of significance at 0.05 
Table 8. Pattern Matrix - Material Wastage

\begin{tabular}{cccccccc}
\hline $\begin{array}{c}\text { SI. } \\
\text { No. }\end{array}$ & Variables & $\begin{array}{c}\text { Total } \\
\text { Experience }\end{array}$ & $\begin{array}{c}\text { Relevant } \\
\text { Experience }\end{array}$ & Groups & Projects & Designation & Department \\
\hline 1 & Concrete & $\checkmark$ & & $\checkmark$ & $\checkmark$ & $\checkmark$ & \\
2 & $\begin{array}{l}\text { Reinforcement } \\
\text { steel }\end{array}$ & & $\checkmark$ & $\checkmark$ & $\checkmark$ & $\checkmark$ & $\checkmark$ \\
3 & Formworks & $\checkmark$ & $\checkmark$ & & & $\checkmark$ & Ü \\
4 & Blocks & $\checkmark$ & $\checkmark$ & & & $\checkmark$ & Ü \\
\hline
\end{tabular}

Notes: F' values of significance at 0.005

' $t$ ' test values of significance at 0.05

Table 9. Perception versus Reality (NP1 and NP2)

\begin{tabular}{|c|c|c|c|c|c|c|c|c|}
\hline \multirow{2}{*}{ Variables } & \multicolumn{4}{|c|}{ NP1 } & \multicolumn{4}{|c|}{ NP2 } \\
\hline & REA & PER & ABS & RES & REA & PER & ABS & RES \\
\hline Engineering & 10 & 11 & -1 & $U$ & 11 & 13 & -2 & $U$ \\
\hline Detailing & 8 & 9 & -1 & $u$ & 10 & 8 & 2 & 0 \\
\hline Material & 12 & 12 & 0 & $P$ & 14 & 12 & 2 & O \\
\hline Storage and handling & 11 & 15 & -4 & $u$ & 12 & 15 & -3 & U \\
\hline Plant and machinery & 14 & 14 & 0 & $P$ & 5 & 14 & -9 & $U$ \\
\hline Production & 9 & 10 & -1 & $u$ & 9 & 9 & 0 & $P$ \\
\hline Execution & 13 & 8 & 5 & $\mathrm{O}$ & 13 & 7 & 6 & O \\
\hline Management & 15 & 13 & 2 & $\mathrm{O}$ & 15 & 11 & 4 & 0 \\
\hline Concrete & 2 & 2 & 0 & $P$ & 2 & 2 & 0 & $P$ \\
\hline Reinforcement steel & 1 & 1 & 0 & $P$ & 1 & 1 & 0 & $P$ \\
\hline Formwork & 7 & 6 & 1 & $\mathrm{O}$ & 8 & 6 & 2 & O \\
\hline Bricks and blocks & 5 & 7 & -2 & $U$ & 7 & 10 & -3 & $U$ \\
\hline Cement & 3 & 3 & 0 & $P$ & 3 & 3 & 0 & $P$ \\
\hline Coarse aggregate & 6 & 5 & 1 & $\mathrm{O}$ & 6 & 5 & 1 & O \\
\hline Fine aggregate & 4 & 4 & 0 & $P$ & 4 & 4 & 0 & $P$ \\
\hline
\end{tabular}

Notes: U - Underestimate; O - Overestimate; P - Precise

REA - Real; PER - Perceived; ABS - Absolute; RES - Result 
Sathiyamurthy Seethapathy and Jane Helena Henderson

Table 10. Perception versus Reality (TP1, TP2 and TP3)

\begin{tabular}{|c|c|c|c|c|c|c|c|c|c|c|c|c|}
\hline \multirow{2}{*}{ Variables } & \multicolumn{4}{|c|}{ TP1 } & \multicolumn{4}{|c|}{ TP2 } & \multicolumn{4}{|c|}{ TP3 } \\
\hline & REA & PER & ABS & RES & REA & PER & ABS & RES & REA & PER & ABS & RES \\
\hline Engineering & 11 & 11 & 0 & $P$ & 12 & 10 & 2 & O & 11 & 7 & 5 & 0 \\
\hline Detailing & 8 & 8 & 0 & $\mathrm{P}$ & 8 & 11 & -3 & $U$ & 9 & 2 & 7 & O \\
\hline Material & 14 & 12 & 2 & O & 14 & 5 & 9 & O & 14 & 5 & 9 & O \\
\hline Storage and handling & 12 & 15 & -3 & $u$ & 11 & 6 & 5 & O & 12 & 10 & 2 & $\mathrm{O}$ \\
\hline Plant and machinery & 5 & 14 & -9 & $u$ & 6 & 9 & -3 & $U$ & 6 & 8 & -2 & U \\
\hline Production & 9 & 9 & 0 & $P$ & 9 & 2 & 7 & O & 10 & 1 & 9 & O \\
\hline Execution & 13 & 7 & 6 & O & 13 & 3 & 10 & O & 13 & 3 & 10 & O \\
\hline Management & 15 & 13 & 2 & O & 15 & 4 & 11 & O & 15 & 4 & 11 & O \\
\hline Concrete & 2 & 2 & 0 & $P$ & 2 & 8 & -6 & $U$ & 2 & 9 & -7 & U \\
\hline Reinforcement steel & 1 & 1 & 0 & $\mathrm{P}$ & 1 & 12 & -11 & $U$ & 1 & 11 & -10 & U \\
\hline Formwork & 7 & 6 & 1 & O & 7 & 7 & 0 & $P$ & 7 & 6 & 1 & O \\
\hline Bricks and blocks & 10 & 10 & 0 & $P$ & 10 & 1 & 9 & O & 8 & 14 & -6 & U \\
\hline Cement & 3 & 3 & 0 & $P$ & 4 & 13 & -9 & $U$ & 3 & 12 & -9 & U \\
\hline Coarse aggregate & 6 & 5 & 1 & O & 5 & 14 & -9 & $U$ & 5 & 13 & -8 & U \\
\hline Fine aggregate & 4 & 4 & 0 & $P$ & 4 & 15 & -11 & $U$ & 4 & 15 & -11 & $u$ \\
\hline
\end{tabular}

Notes: U - Underestimate; O - Overestimate, P - Precise

REA - Real; PER - Perceived; ABS - Absolute; RES - Result

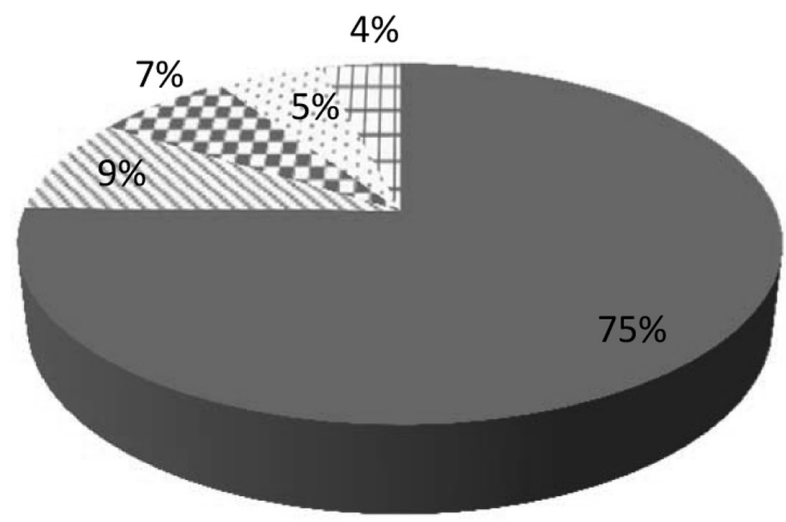

Execution

Procurement

Engineering

Planning

Plant \& Machinery

Figure 3. Demographic - Respondents' Department 


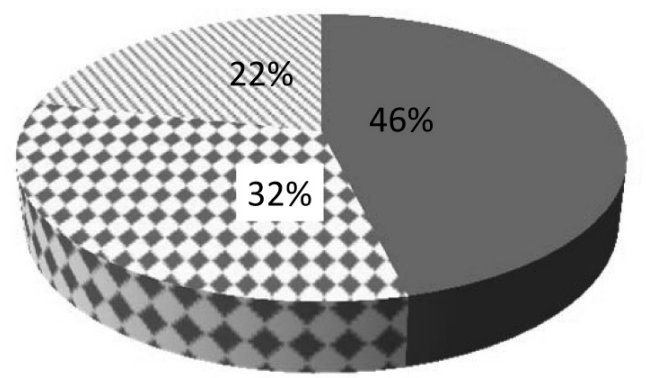

5 to 8 years $\quad$ Below 5 years

Figure 4. Demographic - Respondents' Overall Experience

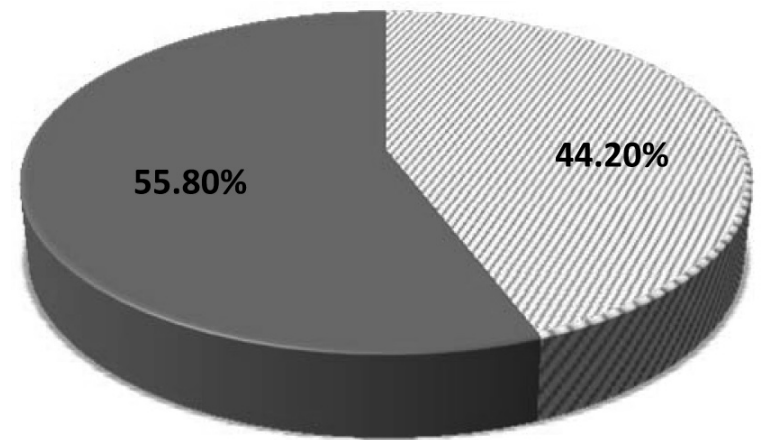

Above 3 years Below 3 years

Figure 5. Demographic - Respondents' Relevant Experience

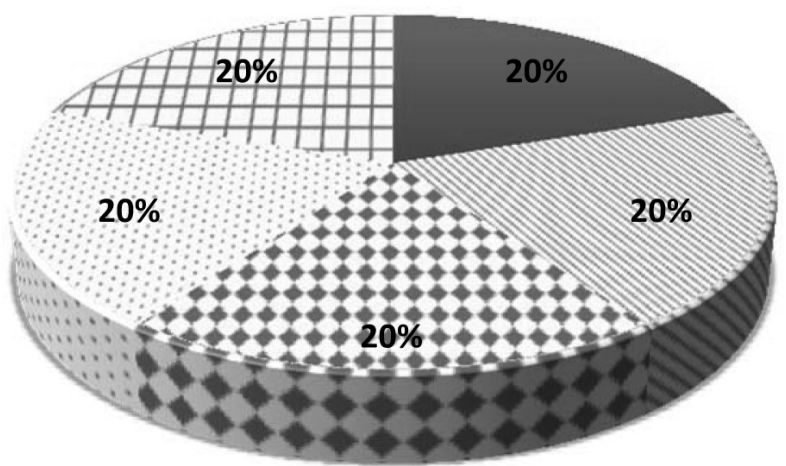

NP-1 NNP-2 :

Figure 6. Demographic - Respondents' Group 


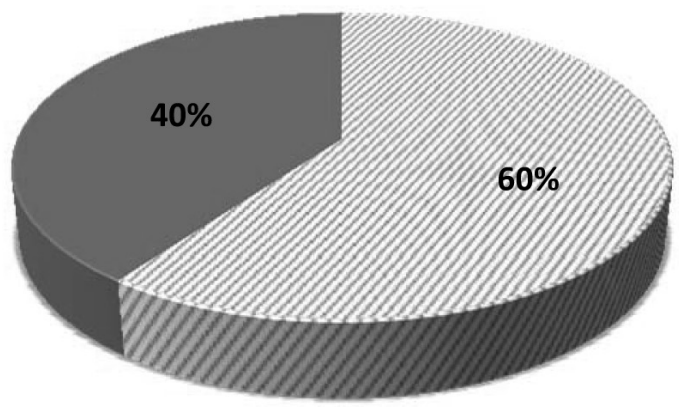

Thermal Power Plant Project

Nuclear Power Plant Project

Figure 7. Demographic - Respondents' Type

In the second nuclear project, $26.6 \%$ of variables pertaining to engineering related, storage and handling related, plant and machinery related issues, and bricks and blocks were underestimated. Likewise, in addition to formwork, and coarse aggregate, $40 \%$ of variables pertaining to detailing related, material related, execution related, and management related issues were overestimated. Moreover, $33.4 \%$ of variables pertaining to production related issues, concrete, reinforcement steel, cement, and fine aggregates were adjudged precisely.

Congruously in the third project, i.e. the first thermal project, $13.4 \%$ of variables pertaining to storage and handling related, and plant and machinery related issues were underestimated. Furthermore, $33.3 \%$ of variables pertaining to material related, execution related and management related issues, formwork and coarse aggregates were overestimated. Besides that, $53.3 \%$ of variables pertaining to engineering related, detailing related, production related issues, concrete, reinforcement steel, bricks and blocks, cement and fine aggregate were adjudged precisely.

Likewise, in the fourth project, i.e. the second thermal project, $47.6 \%$ of variables pertaining to detailing related, plant and machinery related issues, concrete, reinforcement steel, cement, coarse aggregate and fine aggregate were underestimated. In addition, $47.6 \%$ of variables pertaining to engineering related, material related, storage and handling related, production related, execution related, management related issues, and bricks and blocks were overestimated, while $4.8 \%$ of variables pertaining to formworks alone were adjudged precisely.

Finally, in the fifth project, i.e. the third thermal project, $46.6 \%$ of variables pertaining to plant and machinery related issues, concrete, reinforcement steel, bricks and blocks, cement, coarse aggregate and fine aggregates were underestimated. Additionally, 53.4\% of variables pertaining to engineering related, detailing related, material related, storage and handling related, production related, execution related, management related issues, and formworks were overestimated.

Figure 8 shows the absolute difference level of different macro causes of wastage pertaining to planning and execution and procurement and storage. Here, the significance is stressed upon the facet-wise variables based on different type of projects. To decipher further, it is palpable from this depiction that "Plant and machinery" related items were underestimated in four out of five projects. Analogously, "Execution related" and "Management related" issues were overestimated. 
Exploratory Factor Analysis (Park and Kwon, 2011) is a method of data reduction by seeking underlying unobservable (latent) variables that are reflected in the observed variables (manifest variables). It is a technique that requires a large sample size; and based on the correlation matrix of the variables involved, and correlations usually need a large sample size before they stabilize. Additionally, we will use the Principal Component Factoring along with Varimax rotation which is a widely-used method of factor extraction. Here, factor weights are computed to extract the maximum possible variance, with successive factoring continuing until there is no further meaningful variance left. The factor model is then rotated for analysis, which is done by Varimax Rotation.

The overall project cost break-down and individual material cost has been collected from the project planning managers or engineers and the same was verified with respective project physical records. Further project inputs like concrete design mix and form work cycle time along with repetition details were collected. Each project has a marginally varying cost component towards individual issues. Based on the collected data the individual issues have been assigned with relevant material cost component to arrive out the percentage of cost on the overall value of the project.

The probability of such occurrences of each issues and details have been analysed from the site survey and the same was processed for normalising, data cleaning, and reliability check using Cronbach's alpha by SPSS.

Considering Figure 9, department wise and relevant experience results are considerably in cognizance with the overall population mean for each project. Keeping the overall population mean as base, the impact of occurrences of each cause was used to arrive at the percentage of cost impact on the total project by using the following formula:

$$
\% \text { of cost impact of each causes }=p * q * r
$$

where

$\mathrm{p}=$ cost of the individual material,

$q=\%$ of wastage of individual material from factual data from site, and

$r=$ mean of impact of each occurrences (from Questionnaire 1 collected for all the five power plant projects).

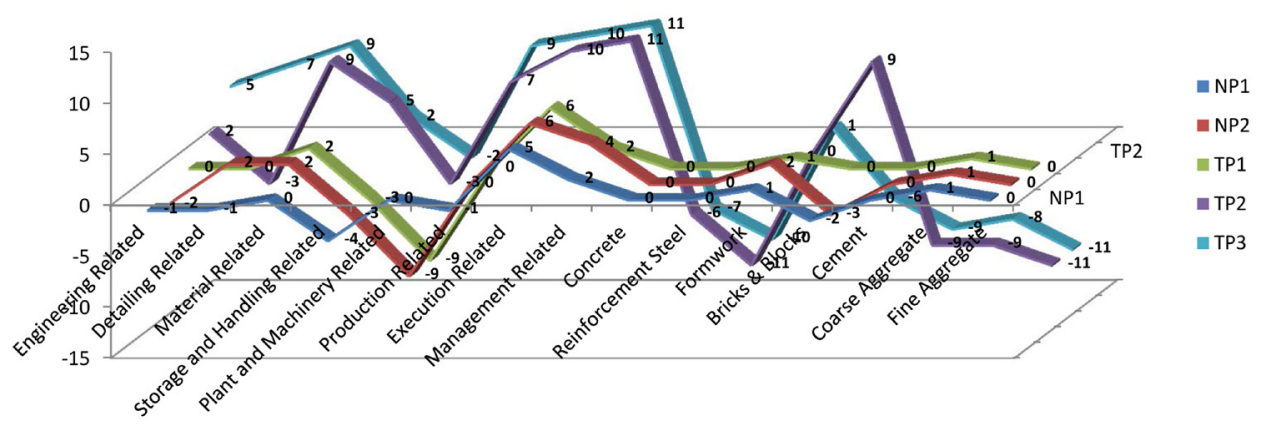

Figure 8. Macro Causes of Wastage in Different Projects 


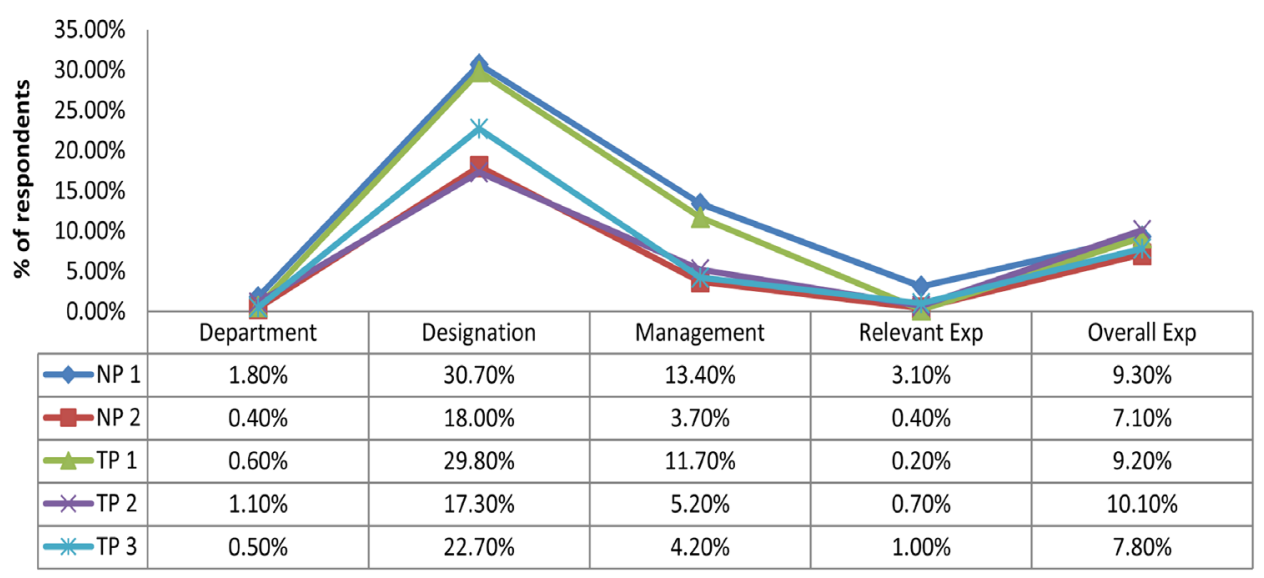

Figure 9. Project wise Overall Mean

The cost of each component was derived from the site records and the causes influencing each issue vary for all the five power plant projects and the percentage of cost impact of total project are calculated and the data are shown in Tables 11 and 12 and Figures 10 and 11.

1. Reinforcement steel wastage $-0.73 \%$ to $0.79 \%$ of total project cost.

2. Concrete wastage $-0.30 \%$ to $0.41 \%$ of total project cost.

3. Cement wastage $-0.24 \%$ to $0.28 \%$ of total project cost.

4. Fine aggregate wastage $-0.09 \%$ to $0.12 \%$ of total project cost.

5. Engineering related issues like delay in issuance of drawings $-0.003 \%$ to $0.004 \%$ of total project cost.

6. Detailing related issues $-0.084 \%$ to $0.099 \%$ of total project cost.

7. Material related issues $-0.007 \%$ to $0.008 \%$ of total project cost.

8. Storage and handling related issues $-0.016 \%$ to $0.019 \%$ of total project cost.

9. Plant and machinery related issues $-0.020 \%$ to $0.027 \%$ of total project cost.

10. Production related issues $-0.030 \%$ to $0.035 \%$ of the total project cost.

11. Execution related issues $-0.008 \%$ to $0.009 \%$ of total project cost.

12. Form work wastage $-0.05 \%$ to $0.07 \%$ of total project cost.

13. Blocks wastage $-0.03 \%$ to $0.07 \%$ of total project cost.

14. Coarse aggregate wastage $-0.06 \%$ to $0.09 \%$ of total project cost.

Pattern analysis was done on the first survey data and total experience displays an eminent effect on $75 \%$ of the criterions namely concrete, formworks, and blocks; while relevant experience and department influences $75 \%$ of the criterion variables namely reinforcement steel, formworks, and blocks. Groups and projects have an equivalent amount of impact by $50 \%$ on concrete and reinforcement steel. Designation has the highest level of prominence on all the criterions as it influences the material wastage causes like concrete, reinforcement steel, formworks, and blocks by $100 \%$.

The top 20 causes based on cost have been tabulated and compiled as Questionnaire 2. The same was given to the two recently completed projects. Questionnaire 2 survey results were tested for concordance between projects. The 
test is used to assess any similarity of opinion between groups on the issues of waste generation. The concordance among the projects was obtained by treating the survey results using Kendall's Coefficient of Concordance. Kendall's W is defined as:

$$
\begin{aligned}
& A=\frac{\sum R_{i}}{n} \\
& d_{i}=R_{i}-A \\
& W=\frac{12 \sum d_{i}^{2}}{m\left(n^{3}-n\right)}
\end{aligned}
$$

where,

W - coefficient of Concordance $(0<W<1)$;

$R_{i}$-sum of ranks assigned to 20 objects by 40 respondents;

$m$ - number of respondents (40); and

$n$ - number of top causes (20).

Table 11. Impact on Total Project Cost - Planning and Execution Stage

\begin{tabular}{clccccc}
\hline Sl. No. & \multicolumn{1}{c}{ Description } & NP-1 & NP-2 & TP-1 & TP-2 & TP-3 \\
\hline A & Engineering related & $0.003 \%$ & $0.004 \%$ & $0.004 \%$ & $0.003 \%$ & $0.004 \%$ \\
B & Detailing related & $0.088 \%$ & $0.084 \%$ & $0.098 \%$ & $0.099 \%$ & $0.086 \%$ \\
C & Material related & $0.008 \%$ & $0.008 \%$ & $0.007 \%$ & $0.008 \%$ & $0.008 \%$ \\
D & Storage and handling related & $0.017 \%$ & $0.017 \%$ & $0.016 \%$ & $0.019 \%$ & $0.018 \%$ \\
E & Plant and machinery related & $0.025 \%$ & $0.025 \%$ & $0.020 \%$ & $0.027 \%$ & $0.026 \%$ \\
F & Production related & $0.030 \%$ & $0.030 \%$ & $0.035 \%$ & $0.032 \%$ & $0.030 \%$ \\
G & Execution related & $0.008 \%$ & $0.008 \%$ & $0.008 \%$ & $0.009 \%$ & $0.008 \%$ \\
H & Management related & $0.001 \%$ & $0.001 \%$ & $0.001 \%$ & $0.001 \%$ & $0.001 \%$ \\
\hline & & $\mathbf{0 . 1 8 0 \%}$ & $\mathbf{0 . 1 7 7 \%}$ & $\mathbf{0 . 1 8 9 \%}$ & $\mathbf{0 . 1 9 8 \%}$ & $\mathbf{0 . 1 8 2 \%}$ \\
\hline
\end{tabular}

Table 12. Impact on Total Project Cost - Procurement, Storage and Usage Stage

\begin{tabular}{clccccc}
\hline SI. No. & \multicolumn{1}{c}{ Description } & NP-1 & NP-2 & TP-1 & TP-2 & TP-3 \\
\hline A & Concrete & $0.37 \%$ & $0.41 \%$ & $0.30 \%$ & $0.37 \%$ & $0.38 \%$ \\
B & Reinforcement steel & $0.77 \%$ & $0.79 \%$ & $0.73 \%$ & $0.78 \%$ & $0.73 \%$ \\
C & Formwork & $0.06 \%$ & $0.05 \%$ & $0.05 \%$ & $0.05 \%$ & $0.07 \%$ \\
D & Blocks & $0.07 \%$ & $0.06 \%$ & $0.03 \%$ & $0.03 \%$ & $0.04 \%$ \\
E & Cement & $0.24 \%$ & $0.28 \%$ & $0.22 \%$ & $0.26 \%$ & $0.26 \%$ \\
F & Coarse aggregate & $0.06 \%$ & $0.06 \%$ & $0.06 \%$ & $0.08 \%$ & $0.09 \%$ \\
G & Fine aggregate & $0.11 \%$ & $0.12 \%$ & $0.09 \%$ & $0.12 \%$ & $0.11 \%$ \\
\hline & & $\mathbf{1 . 6 8 6 \%}$ & $\mathbf{1 . 7 6 4 \%}$ & $\mathbf{1 . 4 7 8 \%}$ & $\mathbf{1 . 6 9 9 \%}$ & $\mathbf{1 . 6 6 9 \%}$ \\
\hline
\end{tabular}




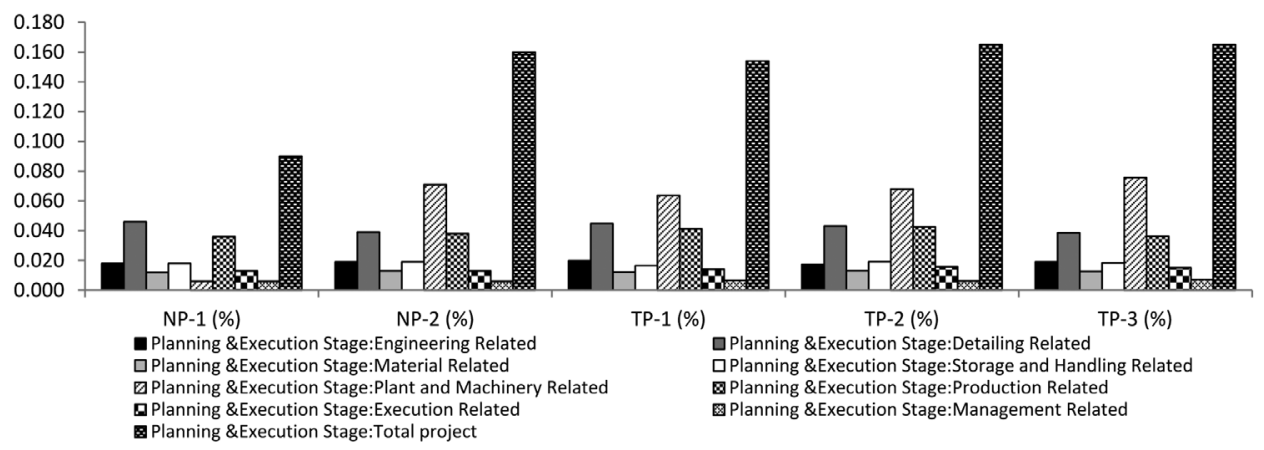

Figure 10. Planning and Execution Stage - Cost Component on Total Project Cost

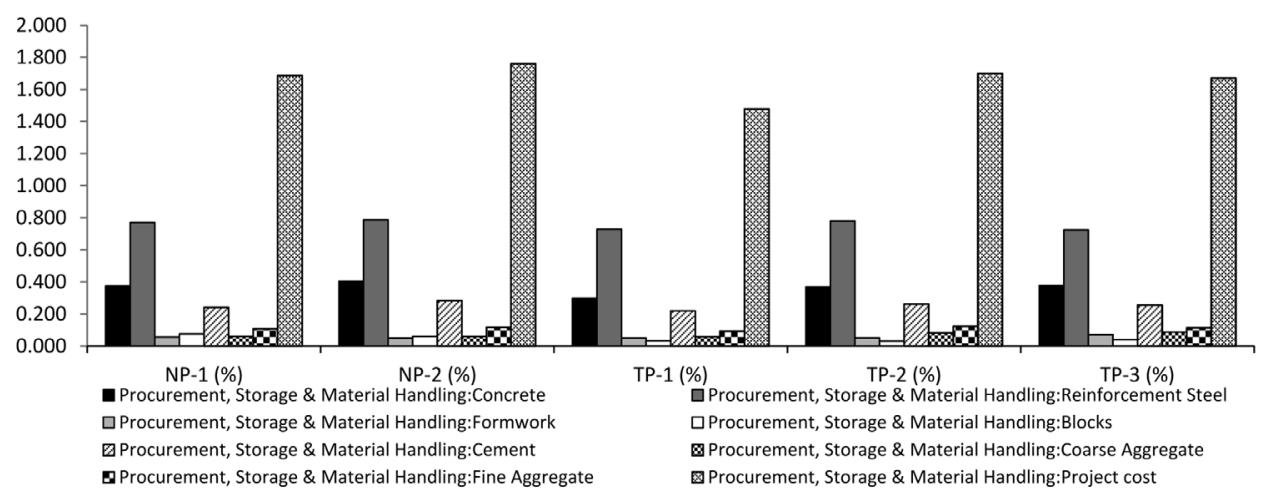

Figure 11. Procurement, Storage and Material Handling - Cost Component on Total Project Cost

If the test statistic $W$ is 1 , then all the judges or survey respondents have been unanimous, and each judge or respondent has assigned the same order to the list of objects or concerns. If $\mathrm{W}$ is 0 , then there is no overall trend of agreement among the respondents, and their responses may be regarded as essentially random. Intermediate values of $\mathrm{W}$ indicate a greater or lesser degree of unanimity among the various judges or respondents.

For the second questionnaire, Kendall's coefficient of 0.717 was obtained as shown in Table 13, which indicates a high agreement between the respondents (Munro et al., 2012) for the levels of agreement resulted on Kendall's test.

Table 13. Test Statistics - Kendall's Concordance (W)

\begin{tabular}{lc}
\hline \multicolumn{1}{c}{$\mathbf{N}$} & $\mathbf{5 0 0}$ \\
\hline Kendall's W & 0.717 \\
Df & 57 \\
\hline Note: $N$ = Sample size; $d f$ = Degree of freedom
\end{tabular}




\section{CONCLUSION AND RECOMMENDATIONS}

This paper demonstrates that the waste generation has direct link with proper project planning, design and engineering, and management. The survey results reveal that different plant capacities, plant locations, source of materials generate different percentage of waste. Although design and engineering for nuclear power plant is standardized, the related issues like issuance of drawings and change in specifications lead to material wastage.

In the material usage stage reinforcement steel is one of the major contributors towards wastage accounting for $0.73 \%$ to $0.79 \%$ of the total project cost. Similarly concrete also contributes towards wastage accounting for $0.30 \%$ to $0.41 \%$ of the total project cost. Out of 58 issues, top 20 issues contributing high value have been listed as follows:

1. Improper cutting plan for reinforcement steel $(0.241 \%$ of the total project cost).

2. Excess quantity ordering of concrete $(0.22 \%$ of the total project cost).

3. Improper storage - cement, fine aggregate, coarse aggregate, and reinforcement steel $(0.289 \%$ of the total project cost).

4. Deficiency in the quantity received - fine aggregates, and reinforcement steel ( $0.023 \%$ of the total project cost).

5. Non-accountable due to rolling margin $(0.142 \%$ of the total project cost).

6. Multiple handling of materials - cement, fine aggregate, and coarse aggregate ( $0.067 \%$ of the total project).

7. Improper maintenance of plant and machinery $(0.084 \%$ of the total project cost).

8. Variance while batching due to improper calibration $(0.082 \%$ of the total project cost).

The major waste generation during planning and execution stage happens in thermal power plant projects whereas issues pertaining to material usage are almost same in both thermal and nuclear power plant projects. Based on the elaborate questionnaire survey and data processed with five different power plant projects the following recommendations are suggested:

1. Implementing proper cutting plan for reinforcement steel using proper software.

2. Make a check list and ensure two level checks by Site and Planning Department.

3. Providing centralized storage space with proper base for fine aggregate, coarse aggregate, and reinforcement steel.

4. Provide separate team to receive the material and ensure monthly reconciliation of receipt with consumption, which is monitored by the top management quarterly.

5. Ensure accounting of rolling margin for every material receipt by planning department and effectively adopt the same in physical execution by construction manager.

6. Proper plan to be made for centralized storage for avoiding multiple handling of fine aggregate, coarse aggregate, and reinforcement steel ensured by Planning Department.

7. Make an exclusive team to monitor and ensure the maintenance of plant and machinery. 
Wastage minimization should be integrated into the construction processes and planned at the initial stage itself. The meticulous planning needs to be adopted in various stages of construction and check points are to be created. Training towards waste reduction to on-site staff is also to be implemented and practiced. Environmental awareness is to be emphasized to the project team. A waste management control system is suggested as part of site management functions, which collects waste generation data, identifies the major areas of waste generation, analyses the causes for the waste generation and gives feedback to the working staff who work on those key areas. The waste control management system can also present the dynamic information to the senior management who can utilize the information and coordinate with various subcontractors and departments for implementing the system more effectively across the organization.

\section{REFERENCES}

Agyekum, K., Ayarkwa, J. and Adinyira, E. (2012). Consultants' perspectives on materials waste reduction in Ghana. Engineering Management Research, 1(1): 138-150. https://doi: 10.5539/emr. vlnlpl38

Alwi, S., Hampson, K. and Mohamed, S. (2002). Waste in the Indonesian construction project. Proceedings of the 1st International Conferences of CIB W107 Creating a Sustainable Construction Industry in Developing Countries. South Africa, 11-13 November 2002, 305-315.

Begum, R.A., Siwar, C., Pereira, J.J. and Jaafar, A.H. (2007). Implementation of waste management and minimisation in the construction industry of Malaysia. Resources, Conservation and Recycling, 51(1): 190-202. https://doi.org/10.1016/j.resconrec.2006.09.004

Chandler, J. (1978). Materials management on building sites, 1st Ed. London: The Construction Press.

Chen, Z., Li, H. and Wong, C.T.C. (2000). Environmental management of urban construction projects in China. Journal of Construction Engineering and Management, 126(4): 320-324. https://doi.org/10.1061/(ASCE)07339364(2000) 126:4(320)

Desa, A., Kadir, N.B.A. and Yusooff, F. (2011). A study on the knowledge, attitudes, awareness status and behaviour concerning solid waste management. Procedia - Social and Behavioural Sciences, 18: 643-648. https://doi. org/10.1016/j.sbspro.2011.05.095

Ekanayake, L.L. and Ofori, G. (2000). Construction material waste source evaluation. In Proceedings of the Second Southern African Conference on Sustainable Development in the Built Environment: Strategies for a sustainable built environment. Pretoria, 23-25 August 2000, 35-36.

EPD. (2002). Environment Hong Kong. Hong Kong: Environment Protection Department.

Ferguson, J., Engineers, I.C., Kermode, N., Nash, C.L., Sketch, W.A. and Huxford, R.P. (1995). Managing and minimizing construction waste: A practical guide. London: Institution of Civil Engineers.

Gavilan, R.M. and Bernold, L.E. (1994). Source evaluation of solid waste in building construction. Journal of Construction Engineering and Management, 120(3): 536-552. https://doi.org/10.1061/(ASCE)0733-9364(1994)120:3(536) 
Hassan, S.H., Aziz, H.A., Adlan, M.N. and Johari, I. (2015). The causes of waste generated in Malaysian housing construction sites using site observations and interviews. International Journal of Environment and Waste Management, 15(4): 295-308. https://doi.org/10.1504/IJEWM.2015.069960

Koshy, R. and Apte, E.M. (2012). Waste minimization of construction materials on bridge site (cement and reinforcement steel) - a regression and correlation analysis. International Journal of Engineering and Innovative Technology, 2(1): 6-14.

Koskela, L. (1992). Application of the new production philosophy to construction, technical report \#72. Stanford, CA: CIFE, Stanford University.

Lam, P.T.I., Chan, E.H.W., Chau, C.K., Poon, C.S. and Chun, K.P. (2011). Environmental management system vs green specifications: How do they complement each other in the construction industry? Journal of Environmental Management, 92(3): 788-795. https://doi.org/10.1016/j.jenvman.2010.10.030

Levin, H. (1997). Systematic evaluation and assessment of building environmental performance (SEABEP). Proceedings of the Second International Conference on Buildings and the Environment. Centre Scientifique et Technique du Batiment, Paris, 9-12 June 1997, 3-10.

McKinsey \& Company. (2008). Powering India-The road to 2017. Karnataka, India: McKinsey \& Company.

Munro, B.H., Plichta, S.B., Kelvin, E. and Kellar, S.P. (2012). Munro's statistical methods for health care research, 6th Ed. Philadelphia: Lippincott Williams and Wilkins.

Park, H.-S. and Kwon, S. (2011). Factor analysis of construction practices for infrastructure projects in Korea. KSCE Journal of Civil Engineering, 15(3): 439445. https://doi.org/10.1007/s12205-011-1064-5

Rashid, M. and Heravi, G. (2012). A lean management approach for power plant construction projects-wastes identification and assessment. In I.D. Tommelein and C.L. Pasquire. 20th Annual Conference of the International Group for Lean Construction. San Diego, USA, 18-20 July 2012.

Richardson, A. (ed.). (2013). Reuse of materials and byproducts in construction: Waste minimization and recycling. London: Springer. https://doi.org/10.1007/978-14471-5376-4

Rogoff, M.J. and Williams, J.F. (1994). Approaches to implementing solid waste recycling facilities. Park Ridge, N.J.: Noyes Publications.

Sakai, S., Yoshida, H., Hirai, Y., Asari, M., Takigami, H., Takahashi, S., Tomoda, K., et al. (2011). International comparative study of 3R and waste management policy developments. Journal of Material Cycles and Waste Management, 13(2): 86-102. https://doi.org/10.1007/s10163-011-0009-x

Shen, L.-Y., LU, W.-S., Yao, H. and Wu, D.-H. (2005). A computer-based scoring method for measuring the environmental performance of construction activities. Automation in Construction, 14(3): 297-309.

Shen, L.Y. and Tam, V.W.Y. (2002). Implementation of environmental management in the Hong Kong construction industry. International Journal of Project Management, 20(7): 535-543. https://doi.org/10.1016/s0263-7863(01)00054-0

Shen, L.Y., Tam, W.Y.V., Chan, C.W.S. and Kong, S.Y.J. (2002). An examination on the waste management practice in the local construction site. Hong Kong Surveyor, 13(1): 39-48.

Shrivastava, S. and Chini, A. (2012). Using building information modeling to assess the initial embodied energy of a building. International Journal of Construction Management, 12(1): 51-63. https://doi.org/10.1080/15623599.2012.10773184 
TIFAC. (ed.). (2000). Utilization of waste from construction industry. New Delhi: Department of Science and Technology.

Tse, R.Y.C. (2001). The implementation of EMS in construction firms: Case study in Hong Kong. Journal of Environmental Assessment Policy and Management, 3: 94-177. https://doi.org/10.1142/S1464333201000637

Winkler, G. (2010). Recycling construction and demolition waste: A LEED-based toolkit (Greensource). New York: McGraw-Hill Professional.

Zainul Abidin, N. (2010). Investigating the awareness and application of sustainable construction concept by Malaysian developers. Habitat International, 34(4): 421-426. https://doi.org/10.1016/j.habitatint.2009.11.011 